\title{
Revitalisasi Rumah Pintar Laskar Pelangi di Gantung melalui Budaya Literasi Humanitas
}

\author{
Kiky Rizki Adi Kurniawan ${ }^{1}$, Nizar Latif ${ }^{2}$, Rahmat Riandi Suparno ${ }^{3}$, Anis Oktaviani ${ }^{4}$, Alfira Fiska \\ Zharifa $^{5}$, Safitri Zuliana Aryanti ${ }^{6}$ \\ ${ }^{1,2,3,4,5,6}$ Fakultas Keguruan dan Ilmu Pendidikan, Universitas Muhamamdiyah Surakarta, Indonesia
}

\section{INFORMASI ARTIKEL}

\author{
Histori Artikel: \\ Submit : 7 Juni 2019 \\ Direvisi : 20 Juni 2019 \\ Diterima : 25 Juni 2019 \\ Publikasi : 1 Juli 2019
}

\section{Kata Kunci:}

revitalisasi

literasi

program solutif

Correspondent Author:

Kiky Rizki Adi Kurniawan

Fakultas Keguruan dan Ilmu Pendidikan

Universitas Muhammadiyah Surakarta,

Indonesia

Email:

a610150038@student.ums.a.cid

\begin{abstract}
ABSTRAK
Kegiatan untuk meningkatkan kegemaran membaca dan menulis yang sedang diterapkan di Indonesia saat ini adalah kegiatan literasi. Kegiatan literasi ini dilaksanakan di Desa Lenggang Kabupaten Belitung Timur sebagai upaya untuk merevitalisasi kembali Rumah Pintar yang tidak digunakan sesuai dengan fungsinya. Tujuan yang akan dicapai dalam rancangan penelitian ini adalah meningkatkan budaya literasi kepada anak-anak yang berada di sekitar rumah pintar Gantung Belitung Timur. Menentukan Tujuan Kegiatan. Tujuan kegiatan PKM ini adalah untuk meningkatkan budaya literasi anak-anak dilingkungan rumah pintar Gantung, Belitung Timur melalui penumbuhan minat baca dan tulis. Tahaptahap penelitian ini adalah sebagai berikut: tahap input, kegiatan yang dilaksanakan adalah melakukan survey kelapangan dan mengumpulkan data primer untuk diidentifikasi, sehingga ditemukan potensi-potensi yang ada serta kendala apa yang dihadapi oleh mitra, merumuskan masalah yang dihadapi mitra, kemudian menyusun solusi untuk mengatasi masalah. Pada tahap proses, kegiatan yang dilakukan berupa pelatihan-pelatihan dan implementasi dari hasil pelatihan membaca dan menulis, sesuai dengan rincian program solutif di atas. Terakhir adalah output, pada tahapan ini kegiatan yang dilaksanakan adalah melakukan evaluasi terhadap kinerja tim pustakawan cilik setelah diberikan pelatihan-pelatihan. Berdasarkan hasil penelitian anak-anak di desa Lenggang memiliki minat belajar yang sangat tinggi. Hal tersebut dapat kami simpulkan berdasarkan kegiatan yang telah kami lakukan di sana selama kurang lebih satu setengah bulan. Melalui kegiatan revitalisasi ini anak-anak dapat meningkatkan kemampuan menyimaknya dan memberi tanggapan terhadap cerita yang diberikan. Berdasarkan kegiatan tersebut dapat disimpulkan bahwa kegiatan literasi tersebut memiliki pengaruh yang sangat besar terhadap perkembangan anak-anak.
\end{abstract}

\section{Pendahuluan}

Kemajuan suatu bangsa tidak hanya dibangun dengan bermodalkan kekayaan alam yang melimpah, maupun pengelolaan tata negara yang mapan, melainkan berawal dari peradaban buku atau penguasaan literasi yang berkelanjutan dari satu generasi ke generasi berikutnya. Namun, yang terjadi saat ini, budaya literasi sudah semakin ditinggalkan oleh generasi muda Indonesia, seiring dengan perkembangan pengetahuan dan teknologi, khususnya di bidang digital. Kegiatan masyarakat, khususnya kaum muda, menggunakan internet lebih banyak sebagai 
sarana hiburan. Padahal, pendidikan berbasis budaya literasi, termasuk literasi digital, merupakan salah satu aspek penting untuk harus diterapkan di sekolah guna memupuk minat dan bakat yang terpendam dalam diri mereka. Walaupun demikian, penguasaan literasi yang tinggi tentunya tidak boleh mengabaikan aspek sosiokultural, karena literasi merupakan bagian dari kultur atau budaya manusia.

Era globalisasi saat ini menuntut semua orang memiliki kemampuan serta kegemaran untuk membaca dan menulis, karena melalui kegiatan tersebut akan menambah wawasan serta keterampilan bagi seseorang. Sebagai contoh saat ini dunia telah dikuasai oleh teknologi informasi seperti gadge, game online dan lain sebagainya. Termasuk di Indonesia yang merupakan negara berkembang membuat masyarakat untuk memiliki teknologi tersebut. Penggunaan gadged sebenarnya tidak dianjurkan untuk anak-anak, tetapi di Indonesia belum ada aturan khusus yang melarang masyarakat (dibawah umur) untuk memiliki gadged seperti di negara-negara maju yang membatasi masyarakatnya untuk penggunaan teknologi informasi. Hal ini sangat berpengaruh terhadap motivasi belajar siswa karena siswa lebih termotivasi untuk menggunakan media tersebut daripada untuk belajar, sehingga siswa lebih banyak menghabiskan waktu dengan memanfaatkan media informasi. Untuk meminimalisir dampak negatif dari kemajuan teknologi informasi tersebut perlu adanya dukungan dari pemerintah maupun pihak sekolah agar anak-anak sebagai penerus masa depan bangsa dapat menjadi manusia yang cerdas dan berpikir kritis. Pihak sekolah sebagai wahana belajar siswa harus memberikan pendampingan bersama agar siswa tidak tergelincir oleh teknologi yang semakin merajalela, dan memanfaatkan teknologi sebagai sarana belajar atau model pembelajaran yang modern.

Budaya literasi di Indonesia sangatlah rendah, hasil tes dan survey PISA (Programme For Student Asesment) yang diselenggarakan negara anggota OECD tahun 2015 menempatkan siswa Indonesia pada peringkat 69 dari 76 negara yang berpartisipasi. Indonesia selama bertahun-tahun tidak memberikan perubahan signifikan terhadap literasi, sehingga membuat pemerintah Indonesia melalui Kementrian Pendidikan dan Kebudayaan menggencarkan kegiatan literasi sejak tahun 2013 sebagai upaya untuk menumbuhkan budaya membaca dan menulis di lingkungan sekolah, dengan literasi diharapkan akan membentuk keiasaan siswa dalam membaca dan menulis. Secara fungsional mengajarkan literasi kepada manusia mampu mengembangkan keterampilan membaca dan metulis. Dengan adanya gerakan literasi diharapkan pendidikan di Indonesia dapat memproduksi manusia berbudi pekerti dan berkarakter.

Tujuan yang akan dicapai dalam rancangan penelitian ini adalah meningkatkan budaya literasi kepada anak-anak yang berada di sekitar rumah pintar Gantung Belitung Timur.

\section{Metode Pelaksanaan}

Metode pelaksanaan ini terbagi menjadi dua yaitu

1. Teknik atau Metode Pelaksanaan

Dalam hal ini gambaran metode pelaksanaan kegiatan adalah sebagai berikut (Gambar 1): 


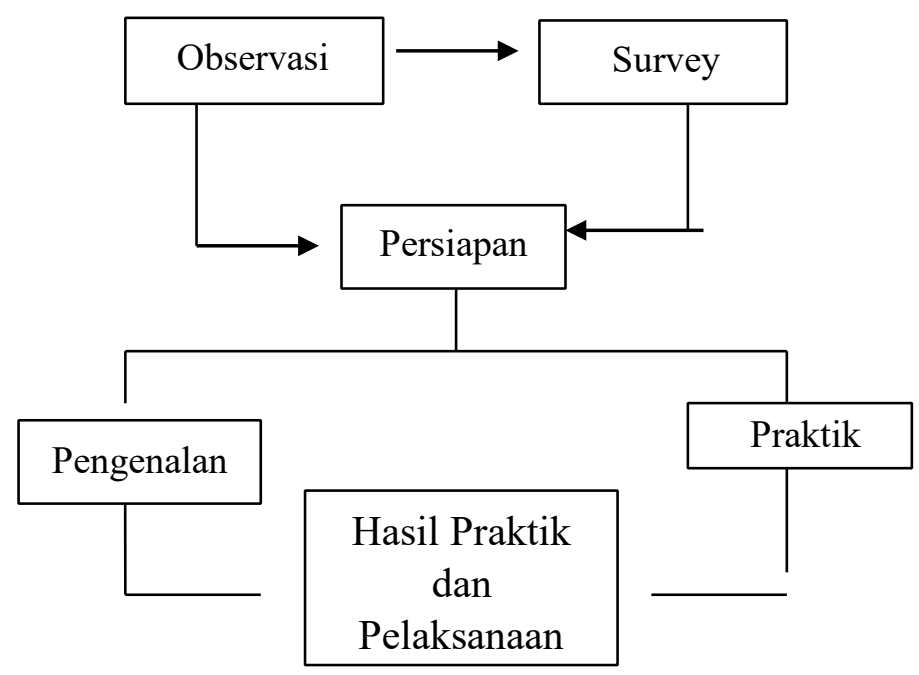

Gambar 1. Diagram Metode Penelitian

2. Cara atau Tahapan Pelaksanaan

Pada tahap persiapan, kegiatan yang dilaksanakan, sebagai berikut.

a) Menentukan Tujuan Kegiatan. Tujuan kegiatan PKM ini adalah untuk meningkatkan budaya literasi anak-anak dilingkungan rumah pintar Gantung, Belitung Timur melalui penumbuhan minat baca dan tulis.

b) Pada tahap input, kegiatan yang dilaksanakan, sebagai berikut.

1) Melakukan survey kelapangan dan mengumpulkan data primer untuk diidentifikasi, sehingga ditemukan potensi-potensi yang ada serta kendala apa yang dihadapi oleh mitra

2) Merumuskan masalah yang dihadapi mitra, kemudian menyusun solusi untuk mengatasi masalah

c) Tahap Proses. Pada tahap proses, kegiatan yang dilakukan berupa pelatihanpelatihan dan implementasi dari hasil pelatihan membaca dan menulis, sesuai dengan rincian program solutif di atas.

d) Output. Pada tahapan ini kegiatan yang dilaksanakan adalah melakukan evaluasi terhadap kinerja tim pustakawan cilik setelah diberikan pelatihan-pelatihan

\section{Hasil Pelaksanaan dan Pembahasan}

Kuliah Kerja Nyata Pendidikan (KKNDik) merupakan mata kuliah intrakurikuler yang diselenggarakan oleh Universitas Muhammadiyah Surakarta (UMS) yang wajib diikuti oleh seluruh mahasiswa Fakultas Keguruan dan Ilmu Pedidikan (FKIP) dengan tujuan meningkatan kemampuan dan wawasan mahasiswa dalam kehidupan bermasyarakat sebagai bekal hidup setelah lulus studi.

Pada dasarnya Kuliah Kerja Nyata Pendidikan (KKN-Dik) merupakan bentuk pengabdian nyata seorang mahasiswa kepada masyarakat yang sebenarnya. Setelah mendapatkan materi perkuliahan yang dapat berguna di lingkungan masyarakat itu sendiri. Kegiatan KKN-Dik juga berfungsi sebagai proses pembelajaran serta pengabdian kepada masyarakat yang sedang membangun dan secara langsung mengidentifikasi serta menangani berbagai masalah yang sedang dihadapi oleh masyarakat. Pelaksanaan KKN-Dik merupakan manifestasi dari Tri Dharma Perguruan Tinggi 
yang ketiga yaitu, pengabdian kepada masyarakat.

Dalam kegiatan pengabdiannya di masyarakat, mahasiswa memberikan pengalaman ilmu pengetahuan, keagamaan dan kemasyarakatan untuk memberikan pengarahan agar dapat memecahkan masalah, dan menanggulanginya secara tepat. Selain itu, pembenahan sarana dan prasarana merupakan kegiatan yang dilakukan serta menjadi program kerja bagi mahasiswa. Melalui KKN-Dik ini, mahasiswa membantu pembangunan dalam masyarakat.

Program KKN-Dik tersebut akan kami laksanakan di Desa Lenggang, Kecamatan Gantung, Kabupaten Belitung Timur. Masyarakat di Desa Lenggang secara personal memiliki potensi yang cukup baik dan beragam. Keragaman yang dimaksud dapat berupa keragaman pandangan terhadap bidang keagamaan. Namun, masyarakat sekitar memiliki rasa toleransi dan kerukunan yang sangat baik. Berdasarkan observasi potensi dan keberagaman yang dimiliki masyarakat, kami akan melaksanakan berbagai kegiatan yang bersifat pendidikan maupun kemasyarakatan di Desa Lenggang.

Rumah Pintar yang berada di desa Lenggang Belitung Timur berdiri pada tahun 2011. Tetapi rumah tersebut tidak dimanfaatkan dengan tujuan awal pembangunan. Pada tahun 2014 rumah pintar diduganakan untuk mahasiswa UGM dalam pelaksanaan KKN di Lenggang Belitung Timur. Setelah digunakan KKN mahasiswa UGM selama 2 bulan, rumah pintar tersebut tidak dimanfaatkan lagi. Mengembalikan kembali fungsi dari rumah pintar desa Lenggang Belitung Timur dengan revitalisasi literasi di daerah tersebut dengan mengadakan pembelajaran bersama dengan anak-anak membantu mengerjakan tugas yang diberikan dari sekolahan dan juga mengajarkan anak anak untuk dapat menceritakan kembali sebuah karangan yang sudah diceritakan.

Usia anak-anak merupakan fase perkembangan yang sangat labil. Pada usia tersebut, anak sangat mudah menerima berbagai hal, baik positif maupun negatif. Apa yang lebih banyak mereka terima pada usia anak-anak, akan sangat menentukan perkembangan intelektual maupun moral mereka pada saat dewasa nanti. Jika mereka lebih banyak diajarkan atau pula dibiasakan untuk gemar membaca, membantu orang lain, sopan, santun, dan berbagai prilaku positif lainnya, kelak mereka besar hal baik itu yang akan terus mereka lakukan karena telah dibiasakan sejak dini.

Oleh karena itu, sejak dini anak-anak harus sudah mulai dibiasakan dan diajarkan hal positif sehingga hal positif itu nanti yang akan mengasah intelektual dan moral mereka jika dewasa nanti. Pada usia prasekolah (0-5 tahun), anak-anak tentu sepenuhnya di bawah asuhan orang tuanya. Sementara pada usia sekolah (612 tahun), pendidikan terhadap anak sudah dibantu oleh para gurunya yang berada di sekolah. Pada usia prasekolah, anak lebih bersifat reseptif. Artinya, anak lebih banyak menerima berbagai masukan (informasi maupun pengalaman) yang diterimanya melalui orang tua, keluarga, maupun lingkungan pergaulannya. Namun, pada usia sekolah anak umumnya sudah mulai produktif. Artinya, anak mulai belajar memproduksi atau mencari informasi maupun pengalamannya sendiri dari realitas kehidupan di sekelilingnya. 
Alangkah bagusnya jika pada masa-masa pencarian maupun produktivitas tersebut, anak disuguhkan dengan berbagai bacaan yang dapat memperkaya intelektual dan moralnya. Salah satu alternatif bacaan yang penting diberikan kepada anak dalam rangka memperkaya intelektual serta membentuk karakter dan budi pekerti anak adalah bacaan karya sastra, lebih khususnya lagi adalah sastra anak. Masa anakanak usia 6-12 tahun memiliki tugas perkembangan untuk mengembangkan kemampuan dasar dalam membaca (Havighurts, 1985). Dalam meningkatkan kemampuan untuk membaca tersebut seorang anak perlu didampingi oleh orang lain. Pendampingan dapat dilakukan oleh orang tua sebagai orang terdekat, guru, dan semua orang di lingkungan terdekat yang mampu mendampingi anak dalam menumbuhkan minat bacanya.

Berbagai penelitian membuktikan bahwa lingkungan, terutama keluarga, merupakan faktor penting dalam proses pembentukan kebiasaan membaca. Gemar membaca tidak tumbuh begitu saja. Anak belajar aksara pertama kali didapat dari rumah mereka melalui interaksi dengan orang tua dan dengan cara yang menyenangkan. Anak merupakan peniru ulung. Jika ingin anak gemar membaca, berikanlah teladan. Orangtua dapat melakuka contoh nyata dengan cara yang menyenangkan untuk menumbuhkan minat membaca, seperti mendongeng, mendeklamasikan puisi, menyanyikan sebuah kisah dari buku cerita, membuat cerita dalam format yang dapat dibuat oleh anak dan orangtua, memainkan peran dalam tokoh di suatu buku cerita dan lain-lain. Intinya, ajak juga anak terlibat aktif dalam kegiatan mencintai buku. Mendongeng itu baik, ketika ia dimaksudkan untuk menumbuhkan budaya gemar membaca melalui pelibatan anak dalam kegiatan itu. Misalnya, dengan memilih dongeng yang akan dibaca. Bukan sekadar mendongeng sementara anak mendengar hingga ia terlelap tidur. Jika itu yang dilakukan, kecenderungan budaya lisan yang didapatkan. Akhirnya sama saja anak tidak suka membaca. Sebagian orang tua mencoba untuk rutin membacakan cerita atau mendongeng sebagai pengantar tidur anak mereka. Ada orang tua mendongeng dengan mengarang cerita mereka sendiri atau membacakan sebuah buku. Sementara orang tua membacakan cerita, anak mendengarkan sambil melihat gambar yang ada dalam buku. Dari sini petualangan imajinasi anak dimulai, bahkan cerita kadang terbawa dalam mimpi. Bukan hanya keluarga, sekolah pun berperan penting dalam pembentukan kebiasaan membaca. Kebiasaan membaca merupakan hasil pembentukan. Keluarga dan sekolah atau lingkungan tempat anak berada berperan penting dalam pembentukan kebiasaan membaca. Anak yang telah terbiasa bergelut dengan sastra sejak usia dini akan menjadi lebih baik karena sastra diciptakan tidak semata-semata untuk menghibur, tetapi lebih dari itu, sastra hadir untuk memberikan pencerahan moral bagi manusia sehingga terbentuk manusia yang berkarakter dan berbudi pekerti luhur. Karya sastra anak menjadi sangat penting dibiasakan kepada anak sejak dini karena di dalamnya tersaji berbagai realitas kehidupan dunia anak dalam wujud bahasa yang indah.

Sastra anak dapat menyajikan dua kebutuhan utama anak yaitu hiburan dan pendidikan Dalam pengertian sederhana, (Nurgiyantoro, 2013:12) mendefinisikan sastra anak sebagai karya sastra yang menempatkan 
sudut pandang anak sebagai pusat penceritaan. Pengertian lain sastra anak adalah karya sastra yang khas (dunia) anak, dibaca anak, serta pada dasarnya dibimbing orang dewasa (Sarumpaet, 2010:3). (Kurniawan, 2009:5) dalam definisinya menyatakan bahwa sastra anak adalah sastra yang dari segi isi dan bahasa sesuai dengan tingkat perkembangan intelektual dan emosional anak. Sementara (Ampera, 2010:10) berpendapat bahwa sastra anak adalah buku bacaan atau karya sastra yang sengaja ditulis sebagai bacaan anak, isinya sesuai dengan minat dan pengalaman anak, sesuai dengan tingkat perkembangan emosi dan intelektual anak.

Dengan demikian, dapat disimpulkan bahwa sastra anak adalah karya sastra yang dasar penciptaan, substansi, dan bahasa yang digunakan sesuai dengan lingkup kehidupan dunia anak Pujangga besar Yunani, Horatius dalam bukunya Ars Poetica menyatakan bahwa tujuan penyair menulis sajak adalah memberi nikmat dan berguna (dulce et utile). Sesuatu yang memberi nikmat atau kenikmatan berarti sesuatu itu dapat memberi hiburan, menyenangkan, menenteramkan, dan menyejukan hati yang susah. Sesuatu yang berguna adalah sesuatu yang dapat memberi manfaat, kegunaan, dan kehikmahan (Teeuw, 1984:183). Fungsi menghibur (dulce) artinya sastra memberikan kesenangan tersendiri dalam diri pembaca sehingga pembaca merasa tertarik membaca sastra. Fungsi mengajar (utile) artinya sastra memberikan nasihat dan penanaman etika sehingga pembaca dapat meneladani halhal positif dalam karya sastra.

Dalam hal ini, sastra memampukan manusia menjadi lebih manusia: mengenal diri, sesama, lingkungan, dan berbagai permasalahan kehidupan (Sarumpaet, 2010:1). Selain dua fungsi di atas, sastra anak mempunyai beberapa fungsi khusus melatih dan memupuk kebiasaan membaca pada anak. Anak lebih suka membaca hanya untuk mencari kesenangan. Niat awal untuk mencari kesenangan dapat dijadikan sebagai jembatan untuk melatih dan membiasakan anak bergelut dengan dunia buku. Jika anak telah terbiasa membaca bacaan anak, maka akan merangsang kebiasaan atau hobinya untuk membaca buku pelajaran dan buku umum lainnya.

Kemampuan litreasi dapat diperkenalkan atau diajarkan kepada anak sejak anak berada dalam kandungan. Caranya sangat mudah, dengan menstimulasi jabang bayi dengan sebuah bacaan, cerita, atau dongeng, dan mendeklamasikan puisi sejak dalam kandungan. Setelah lahir anak tersebut, perkembangan otak kiri dan kanannya akan seimbang dan kecerdasan berbahasanya pun akan lebih unggul.Teruskan memberi rangsangan yang sifatnya menyenangkan sesuai dengan fase perkembangan anak (Suyadi, 2010). Anak usia 18 bulan hingga empat tahun memiliki "rasa ingin tahu" yang amat besar (Doman, 1987). Jadi, menumbuhkan minat baca sejak dini bahkan sejak anak mengenal huruf. Sejak lahir sampai dengan usia 6 tahun anak usia dini sudah mempunyai kemampuan dalam literasi, meskipun tidak belajar secara khusus tetapi anak belajar literasi melalui interaksi dengan lingkungan tempat anak tinggal (Montessori \& Maturationis (Morrison, 2012).

Mengenalkan dan membelajarkan membaca bagi anak usia dini dapat dilakukan dengan melalui aktivitas bermain. Tujuan membelajarkan literasi kepada anak ialah membaca untuk belajar atau dengan perkataan 
lain membaca untuk kesenangan. Menstimulasi perkembangan membaca anak dan orang tua dapat dilakukan dengan membuat kartu huruf dan dapat dituliskan dengan suku kata dan kata. Belajar membaca pada anak usia dini akan membawa dampak positif bagi perkembangan mereka. Pengenalan kartu huruf, kartu kata sejak usia dini menjadikan otak mereka lebih terasah dan mudah untuk menyerapkan sesuatu.

Membaca dapat dikatakan sebagai proses untuk mendapatkan informasi yang terkandung dalam suatu teks bacaan untuk memperoleh pemahaman atas bacaan tersebut. Membaca merupakan sebagai proses membunyikan lambang tertulis. Membaca awal sering disebut sebagai membaca nyaring atau membaca permulaan. Lebih lanjut hasil riset menegaskan bahwa membaca nyaring memiliki pengaruh positif lain, seperti mempererat hubungan kasih sayang orang tua dan anak, mengenalkan anak pada bahasa lisan dan tulis, meningkatkan kemampuan berbahasa anak, membuat anak menikmati dunia belajar sebagai hiburan, dan sekaligus memperluas wawasan dan pengetahuan mereka (Abidin, 2013).

Kemampuan membaca secara langsung berhubungan dengan kemampuan menulis yang baik sebab orang yang jarang membaca akan mengalami kesulitan dalam menemukan kosa kata ketika menulis. Membaca dapat membangun pondasi yang kuat untuk dapat mempelajari dan memahami berbagai disiplin ilmu. Seperti pepatah mengatakan "Buku adalah Jendela Dunia". Hal tersebut memang benar sebab dengan adanya buku anak akan mengetahui berbagai informasi yang ada diseluruh dunia baik itu mengenai sejarah, pengetahuan umum, maupun hal yang lainnya.
Kebiasaan membaca harus selalu dibiasakan mulai sejak dini. Ketrampilan membaca dapat meningkatkan kemampuan seseorang untuk memahami berbagai konsep dengan mudah. Hal ini mengembangkan keterampilan berpikir kritis pada anak. Memahami konsep dan pemikiran kritis adalah dua kualitas penting dari seorang individu yang sukses. Selain itu, membaca juga meningkatkan kosa kata anak, perintah pada bahasa, dan kemampuan komunikasi. Anak yang membaca mampu berkonsentrasi pada pelajaran mereka dan lebih baik daripada naka yang tidak. Kesadaran literasi merupakan pintu gerbang mengenal dunia yang luas ini. Harap diperhatikan bahwa kesadaran literasi bukan sekadar menguasai keterampilan dasar dalam membaca dengan melihat huruf yang disusun dan disejajarkan. Lebih dari itu, kesadaran literasi adalah memahami satu kandungan masalah dari apa yang dibacanya yang kemudian ia dapat menggunakan dan menginternalisasikannya menjadi sebuah pemahaman. Kesadaran literasi itu penting untuk ditumbuhkembangkan, karena dapat membuat anak menjadi cerdas dalam melihat masalah dalam kehidupannya. Anak yang memahami masalah secara otomatis mampu mencarikan solusi atas masalah tersebut. anak yang cerdas akan membuat bangsa kita maju.

\section{Simpulan}

Rumah Pintar yang terdapat di Desa Lenggang, Gantung, Kabupaten Belitung timur tidak dimanfaatkan sesuai dengan fungsinya. Oleh karena itu mahasiswa KKN Dik FKIP UMS berusaha untuk merevitalisasi Rumah Pintar melalui kegiatan literasi humanitas yang dapat menghidupkan atau memfungsikan 
kembali Rumah Pintar yang dibangun pada era Presiden SBY tersebut. Mengembalikan kembali fungsi dari rumah pintar desa Lenggang Belitung Timur dengan revitalisasi literasi di daerah tersebut dengan mengadakan pembelajaran bersama dengan anak-anak membantu mengerjakan tugas yang diberikan dari sekolahan dan juga mengajarkan anak anak untuk dapat menceritakan kembali sebuah karangan yang sudah diceritakan. Anak-anak di desa Lenggang memiliki minat belajar yang sangat tinggi. Hal tersebut dapat kami simpulkan berdasarkan kegiatan yang telah kami lakukan di sana selama kurang lebih satu setengah bulan. Melalui kegiatan revitalisasi ini anak-anak dapat meningkatkan kemampuan menyimaknya dan memberi tanggapan terhadap cerita yang diberikan. Berdasarkan kegiatan tersebut dapat disimpulkan bahwa kegiatan literasi tersebut memiliki pengaruh yang sangat besar terhadap perkembangan anak-anak.

\section{Daftar Pustaka}

Abidin, Y. 2013. Pembelajaran Bahasa Berbasis Pendidikan Karakter. Bandung: Refika Aditama
Ampera, Taufik. 2010. Pengajaran Sastra Teknik Mengajar Sastra Anak. Berbasis Aktivitas. Bandung: Widya Padjadjaran.

Doman, G. 1987. Mengajar Bayi Anda Membaca. Jakarta: Gaya Favorit Press.

Havighurts, Robert. J. 1985. Human Development and Education. Terjemahan Moh. Kasiran. Surabaya: Sinar Jaya.

Kurniawan, Heru. 2009. Sastra Anak dalam Kajian Strukturalisme, Sosiologi, Semiotika, hingga Penulisan Kreatif. Yogyakarta: Graha Ilmu.

Morrison, S. G. 2012. Dasar-Dasar Pendidikan Anak Usia Dini. Jakarta: PT Indeks

Nurgiyantoro, Burhan. 2013. Sastra Anak Pengantar Pemahaman Dunia Anak. Yogyakarta: Gadjah Mada. University press.

Sarumpaet, Riris K. Toha. 2010. Pedoman Penelitian Sastra Anak. Jakarta: Obor Suyadi. 2010. Psikologi Belajar PAUD. Pedagogia: Jogjakarta.

Teeuw, A. 1984. Sastra dan Ilmu Sastra. Jakarta: Pustaka Jaya. 